\title{
latrogenic deaths: A 25-year retrospective study of medicolegal autopsies
}

\author{
Pernille Østergaard Petersen* and Lene Warner Thorup Boel
}

Department of Forensic Medicine, Aarhus University, 8200, Denmark (DK)

*Corresponding author pernille_oestergaard@live.dk

\begin{abstract}
:
Background: It is stipulated in the Danish Health Act that any death which could be caused by a mistake, neglect or accident in relation to treatment or prophylaxis should be reported to the police. It is then within the power of the police to request a medicolegal autopsy. Aim: To profile the possible iatrogenic deaths in relation to different characteristics.

Methods: All cases from 1992 to 2015 registered as doctor's malpractice were selected. Cases from 2016 were selected based on the autopsy introduction. Included cases were analyzed focusing on different characteristics: type of iatrogenic event, responsible medical professional, place of death, cause of death.

Results: A total of 275 , i.e. $2.5 \%$ possible iatrogenic deaths out of a total of 11,143 autopsies were included. The most frequent type of iatrogenic event was negligence (42.2\%). Most often a hospital doctor was the responsible party including surgeons $(40 \%)$ and physicians $(13.5 \%)$. The three most common causes of death were cardiovascular disease (22.2\%), infection/inflammation (17.8\%) and hemorrhage $(16 \%)$.

Conclusion: The results from this study can contribute to the knowledge of what to be aware of when dealing with the death of a
\end{abstract} person who has been in contact with the health care system.

Keywords:

Malpractice, medical malpractice, forensic science, autopsy, cause of death, forensic medicine, death, forensic pathology, medical error and patient safety.

\section{INTRODUCTION}

In our society there is an increasing focus on patient safety and therefore also on the manner in which medical professionals conduct their practice. This has been discussed not only in the media1-3 but also politically. In Denmark the latter was manifested in 2015 by the political decision to establish the Danish Patient Safety Authority with the key assignment to secure patient safety.4 Every year the authority publishes data on registered/investigated unintended events following medical interventions, some of which have a fatal outcome.5 In an editorial from the British Medical Journal, the author declares errors in medical practice a serious public health care problem and urges medical professionals to talk about errors with the purpose of learning and prevention. 6

latrogenic deaths are caused by medical professionals either by their advisement, decisions, or treatment. This may be due to insufficient or wrong diagnosis, complications during invasive procedures or treatment with medications.7 The Danish Health Act (DHA) states that the police must be notified when a death could be the result of a mistake, due to neglect or an accident in relation to medical treatment or prophylaxis. 8 The responsibility for notifying the police lies with the doctor pronouncing the death. It is then within the power of the police to determine whether further investigation is necessary. They can then request an inquest performed by the Danish Patient Safety Authority. Given the information from the inquest, the police, in collaboration with the Danish Patient Safety Authority, decide whether a medicolegal autopsy is relevant. Medicolegal autopsies are performed at the Departments of Forensic Medicine in Aarhus, Copenhagen or Odense, respectively. This way of handling deaths serves to secure the legal rights of patients but also to secure patient safety by allowing the Danish Patient Safety Authority to supervise the performance of the health care system. Therefore, when investigating iatrogenic deaths, files from the Department of Forensic Medicine is a valid source of information.

The aim of this study is to profile the possible iatrogenic deaths in relation to different characteristics.

\section{METHOD}

This retrospective study was carried out by studying archived files from autopsies performed at the Department of Forensic Medicine, Aarhus University during the 25-year period from 1992 to 2016. All cases from this period of time registered as possible iatrogenic death by the forensic pathologist were extracted from the database "RPA sager". Cases coded as "iatrogenic death" were selected. The term "iatrogenic death" was not a default code but was added as a free code in the registration system. In the last year (2016), the coding practice has changed, meaning that free codes are no longer in use. The cases from this year were therefore selected from the autopsy introduction, where the motivation for the autopsy is stated.

During the 25-year period, 326 cases were retrieved from a total of 11,143 autopsies conducted at the Department of Forensic Medicine. Of the 326 cases, six files could not be found, and one case was not closed yet, and these 
were therefore not included in the study. The remaining 319 cases were read, including the autopsy report, additional analysis, the police report and relevant extracts from the patients' hospital records. From these files, relevant information regarding the different characteristics was extracted. After reading the available cases, a further 44 cases were excluded, either because there was no reason to suspect an iatrogenic death, or because this suspicion was disproven by the result of the medicolegal autopsy. The decision to exclude any case was made by the person reviewing the files (PøP, medical student) always in collaboration with a forensic pathologist (LWB, professor), who was also consulted when there was doubt regarding classification.

The 275 cases included in this study were analysed focusing on different characteristics. General characteristics such as gender, age at the time of death, year of death and place of death were registered. In addition to this, more specific characteristics were registered as well, including cause of death, type of iatrogenic event, and finally the group of medical professions who were assessed as responsible for the iatrogenic event. Five groups of medical professionals were defined: physicians covering doctors from internal medical specialities, surgeons, general practitioners, doctors from the emergency service and other health care personnel including nurses, nursing aides, midwives and radiographers. For the purpose of comparability, the same classification regarding type of iatrogenic event used in other studies was applied (Table 1).9-11 For the same reason, cause of death was classified in nearly the same categories as Sørensen et al.11 Thus classifying cause of death as infection/ inflammation, cardiovascular disease, CNS lesions, haemorrhage, perforated intestine, poisoning, asphyxia, unknown and other. The cause of death was unknown in five cases. In these five cases, the patients had all been in contact with a doctor prior to their death. The cases were included because the doctor did not realize how severe the patient's condition was, and therefore did not take the necessary precautions, which possibly could have changed the outcome.

Table 1. Type of event

\begin{tabular}{|c|c|}
\hline $\begin{array}{c}\text { Group } 1 \\
\text { Negligence }\end{array}$ & $\begin{array}{l}\text { Omitting necessary care } \\
\text { Insufficient diagnostics } \\
\text { Wrong diagnose } \\
\text { Delayed hospitalization }\end{array}$ \\
\hline $\begin{array}{l}\text { Group } 2 \\
\text { Complications due to } \\
\text { invasive procedures }\end{array}$ & $\begin{array}{c}\text { Intraoperative complications } \\
\text { Exitus in tabula } \\
\text { Complications due to endoscopy procedures } \\
\text { Postoperative complications } \\
\text { Anaesthetic mishaps }\end{array}$ \\
\hline $\begin{array}{c}\text { Group } 3 \\
\text { Inappropriate treat- } \\
\text { ment }\end{array}$ & $\begin{array}{l}\text { Transfusion reaction } \\
\text { Inappropriate prescription of medicine } \\
\text { Lack of treatment despite known treatable condition } \\
\text { (e.g. hypoglycaemia) }\end{array}$ \\
\hline $\begin{array}{c}\text { Group } 4 \\
\text { Suboptimal care }\end{array}$ & $\begin{array}{l}\text { Wrong positioning of patient } \\
\text { Lack of prescribed observation } \\
\text { Delayed reaction to signalling device }\end{array}$ \\
\hline $\begin{array}{c}\text { Group } 5 \\
\text { Adverse drug event }\end{array}$ & Wrong drug, dose, frequency, or administration \\
\hline
\end{tabular}

All descriptive statistics and the $\chi 2$-tests were conducted using SPSS with the significance level set at 0.05 .

\section{RESULTS}

\section{Medicolegal autopsies through 25 years}

During the 25-year period, a total of 275 autopsy cases with an iatrogenic event as the possible cause of death were identified. The frequency of possible iatrogenic deaths among the total number of medicolegal autopsies were on average $2.5 \%$ and varied from a minimum of $0.7 \%$ in 2008 to a maximum of $12.4 \%$ in 2016 .

\section{General characteristics (gender, age and place of death)}

The study population consisted of $123(44.7 \%)$ women and 152 (55.3\%) men. The median age was 59.0 years (range $0-96$ years). The distribution of cases within the different age groups is shown in figure 1. The most common place of death was at hospital, with a total of 195 (70.9\%) deaths. There seem to be an equal distribution as to whether the death occurred in an intensive care unit, a medical ward or in a surgical ward (Table 2).

\section{Type of iatrogenic event}

Two types of iatrogenic events appear to occur in higher frequency compared to the rest, namely negligence in 116 (42.2\%) cases, and complications due to invasive procedures in 111 (40.4\%) cases (Table 3). Of those who died at home, neglect was the type of event that had preceded the death in $43 / 49$ (87.8\%) cases. Among the cases with negligence as type of iatrogenic event, the most common and second most common cause of death was respectively cardiovascular disease (34/116, 29.3\%) and infection/ inflammation (28/116, 24.1\%).

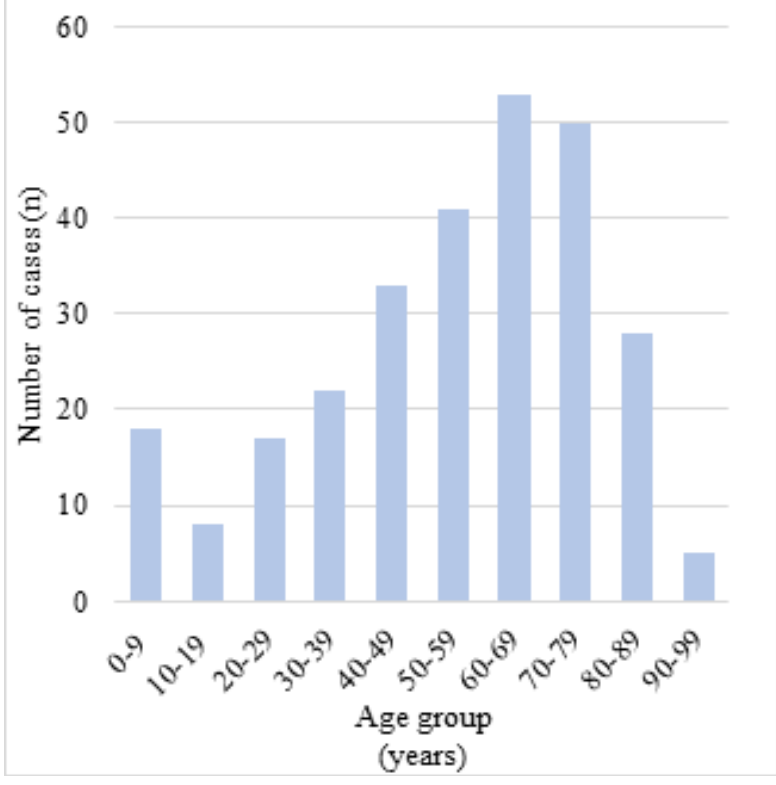

Figure 1. Distribution of cases within age groups. 
Table 2. Distribution of cases within place of death

\begin{tabular}{ccc}
\hline & Place of death & $\begin{array}{c}\text { Number of cases } \\
\mathrm{n}(\%)\end{array}$ \\
\hline Hospital & Medical ward & $60(21.8)$ \\
Surgical ward & $43(15.6)$ \\
Intensive care unit & $66(24.0)$ \\
Not specified & $26(9.5)$ \\
At home & $49(17.8)$ \\
& In an institution & $13(4.7)$ \\
Other & $18(6.5)$ \\
\hline
\end{tabular}

Table 3. Distribution of cases within type of iatrogenic event

\begin{tabular}{cc}
\hline Type of iatrogenic event & $\begin{array}{c}\text { Number of cases } \\
\mathrm{n}(\%)\end{array}$ \\
\hline Negligence & $116(42.2)$ \\
Complications due to invasive procedures & $111(40.2)$ \\
Adverse drug events & $33(12)$ \\
Inappropriate treatment & $8(2.9)$ \\
Suboptimal care & $7(2.5)$ \\
\hline
\end{tabular}

When the iatrogenic event was complications due to invasive procedures, the hospital was almost always the place of death (108/111,97.3\%), and the most common cause of death was haemorrhage (34/111, 30.6\%) followed by perforated intestine $(21 / 111,18.9 \%)$.

Adverse drug events occurred in 33 (12\%) cases, of which 13 (39.4\%), were poisoning deaths. Other causes of death in this group were infection/ inflammation $(7 / 33,21.2 \%)$ and cardiovascular disease $(6 / 33,18.2 \%)$.

We used a $\chi^{\wedge}$ 2-test to investigate whether there were any significant changes in the occurrence of type of iatrogenic events throughout the 25- year period. The occurrence of negligence as type of iatrogenic event was significantly different over the years ( $p$-value $<0.05$, Table 4 ). However, there were no significant changes of the occurrence of complications due to invasive procedures and inappropriate treatment. Unfortunately, there were not enough cases to establish whether a significant change in frequency in wrong treatment and suboptimal care occurred.

\section{Cause of death}

The majority of cases died from one of the three most frequent causes of death: cardiovascular disease (22. 2\%), infection/ inflammation (17.8\%), or haemorrhage (16\%). Neglect was the type of iatrogenic event that most often preceded death, when the cause of death was either cardiovascular disease $(34 / 61,55.7 \%)$ or infection/inflammation (28/49, 57.1\%). When death was caused by haemorrhage, the most frequent iatrogenic event was complications due to invasive procedures $(34 / 44,77.3 \%)$. The remaining 10/44 (22.7\%) were caused by neglect (Table 5).

A perforated intestine and its secondary complications were the cause of death in 34 (13.5\%) of all cases. Of these, 21/34 (56.8\%) cases the iatrogenic event was a complication due invasive procedure, and in $26 / 34$ (70.3\%) cases the responsible medical professional was a surgeon. The same tendency is somewhat present among cases with asphyxia as cause of death. Asphyxia as cause of death comprised 28 (10.2\%) cases, and in 13/28 (46.4\%) cases the type of iatrogenic event was a complication due to invasive procedures. In $14 / 28(50 \%)$ cases the responsible medical professional was a surgeon.

\section{Responsible medical profession}

The largest group of health care professionals assessed as responsible for the iatrogenic events were hospital doctors, including surgeons and physicians.

Table 4. Occurrence of type of event throughout the 25-year period

\begin{tabular}{|c|c|c|c|c|c|c|c|c|}
\hline & \multirow{2}{*}{$\begin{array}{c}1992-1996 \\
n(\%)\end{array}$} & \multicolumn{7}{|c|}{ 5-year interval } \\
\hline & & $\begin{array}{c}1997-2001 \\
n(\%)\end{array}$ & $\begin{array}{c}2002-2006 \\
n(\%)\end{array}$ & $\begin{array}{c}2007-2011 \\
n(\%)\end{array}$ & $\begin{array}{c}2012-2016 \\
n(\%)\end{array}$ & $\begin{array}{l}\text { Total } \\
\mathrm{n}(\%)\end{array}$ & P-value & \\
\hline \multirow{9}{*}{ 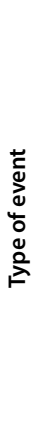 } & \multirow[t]{2}{*}{ Neglect } & 33 & 36 & 15 & 7 & \multirow[t]{2}{*}{$25(21.6)$} & 116 & \multirow[t]{2}{*}{$<0.000$} \\
\hline & & $(28.4)$ & $(31.0)$ & (12.9) & $(6.0)$ & & $(100)$ & \\
\hline & Complications due to & 25 & 21 & 14 & 22 & 29 & 111 & 0.056 \\
\hline & invasive procedures & (22.5) & (18.9) & (12.6) & (19.8) & $(26.1)$ & $(100)$ & \\
\hline & \multirow[t]{2}{*}{ Wrong treatment } & 2 & 1 & 1 & 1 & 3 & 8 & \multirow[t]{2}{*}{ * } \\
\hline & & $(25.0)$ & (12.5) & $(12.5)$ & $(12.5)$ & (37.5) & $(100)$ & \\
\hline & \multirow[t]{2}{*}{ Suboptimal care } & 1 & 1 & 1 & 0 & 4 & 7 & \multirow[t]{2}{*}{ * } \\
\hline & & (14.3) & (14.3) & $(14.3)$ & $(0.0)$ & $(57.1)$ & $(100)$ & \\
\hline & Inappropriate treatment & $\begin{array}{c}4 \\
(12.1)\end{array}$ & $\begin{array}{c}11 \\
(33.3)\end{array}$ & $\begin{array}{c}4 \\
(12.1)\end{array}$ & $\begin{array}{c}6 \\
(18.2)\end{array}$ & $\begin{array}{c}8 \\
(24.2)\end{array}$ & $\begin{array}{c}33 \\
(100)\end{array}$ & 0.255 \\
\hline
\end{tabular}

*No valid P-value due to expected frequency is less than 5. 
Table 5. Type of iatrogenic event within cause of death

\begin{tabular}{|c|c|c|c|c|c|c|c|}
\hline & Neglect & & & & vent & & \\
\hline & & $\begin{array}{c}\text { Complication due to } \\
\text { invasive procedures } \\
\mathrm{n}(\%)\end{array}$ & $\begin{array}{l}\text { Inappropriate treatment } \\
\mathrm{n}(\%)\end{array}$ & $\begin{array}{c}\text { Suboptimal care } \\
\mathrm{n}(\%)\end{array}$ & $\begin{array}{c}\text { Adverse drug event } \\
\mathrm{n}(\%)\end{array}$ & $\begin{array}{l}\text { Total } \\
\mathrm{n}(\%)\end{array}$ & \\
\hline & $\begin{array}{l}\text { Cardiovascular } \\
\text { disease }\end{array}$ & $34(55.7)$ & $17(27.9)$ & $3(4.9)$ & $1(1.6)$ & $6(9.8)$ & $61(100)$ \\
\hline & $\begin{array}{l}\text { Infection/ } \\
\text { inflammation }\end{array}$ & $28(57.1)$ & $13(26.5)$ & $0(0.0)$ & $1(2.0)$ & $7(14.3)$ & $49(100)$ \\
\hline 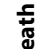 & Haemorrhage & $10(22.7)$ & $34(77.3)$ & $0(0.0)$ & $0(0.0)$ & $0(0.0)$ & $44(100)$ \\
\hline E & Perforated intestine & $16(43.2)$ & $21(56,8)$ & $0(0.0)$ & $0(0.0)$ & $0(0.0)$ & $34(100)$ \\
\hline $\bar{\pi}$ & Asphyxia & $8(28.6)$ & $13(46.4)$ & $1(3.6)$ & $4(14.3)$ & $2(7.1)$ & $28(100)$ \\
\hline & Poisoning & $4(23.5)$ & $0(0.0)$ & $0(0.0)$ & $0(0.0)$ & $13(76.5)$ & $17(100)$ \\
\hline & CNS lesion & $6(40.0)$ & $4(26.7)$ & $2(13.3)$ & $1(6.7)$ & $2(13.3)$ & $15(100)$ \\
\hline & Unknown & $4(80)$ & $0(0.0)$ & $0(0.0)$ & $0(0.0)$ & $1(20)$ & $5(100)$ \\
\hline & Other & $6(31.6)$ & 9 (47.4) & $2(10.5)$ & $0(0.0)$ & $2(10.5)$ & $19(100)$ \\
\hline
\end{tabular}

Surgeons accounted for 110 (40.0\%) of the cases and physicians for 37 (13.5\%) (Table 6). In the majority of these cases, hospital was the place of death. Interestingly the most common iatrogenic event was the same among physicians and surgeons, namely complication due to invasive procedures, occurring in 85/110 (77.3\%) when a surgeon was involved, and 15/37 (40.5\%) when a physician was involved (Figure 2).

Table 6. Distribution of cases within group of responsible medical professional

\begin{tabular}{lc}
\hline Responsible medical professional & $\begin{array}{c}\text { Number of cases } \\
\mathrm{n}(\%)\end{array}$ \\
\hline Surgeon & $110(40.0)$ \\
Physician & $37(13.5)$ \\
General practitioner & $33(12.0)$ \\
Doctors from the emergency service & $34(12.4)$ \\
Other & $22(8)$ \\
Not specified & $39(14.2)$ \\
\hline
\end{tabular}

General practitioners and doctors from the emergency service were responsible for approximately the same amount of cases: 33 (12.0\%) and $34(12.4 \%)$, respectively. In cases where a general practitioner had been consulted, the most common place of death was at home 17/33 (51.5\%), with the most frequent type of iatrogenic event being negligence $29 / 33$ (84.8\%). Cause of death was cardiovascular disease in 14/33 (42.4\%) cases.

When doctors from the emergency service had been consulted, the same pattern occurred in regard to place of death and type of event: 19/34 (55.9\%) died at home, and almost all deaths (33/34 (97.1\%)) were due to negligence. In regard to cause of death, the most frequent cause in this group was infection/inflammation 11/34 (32.4\%).

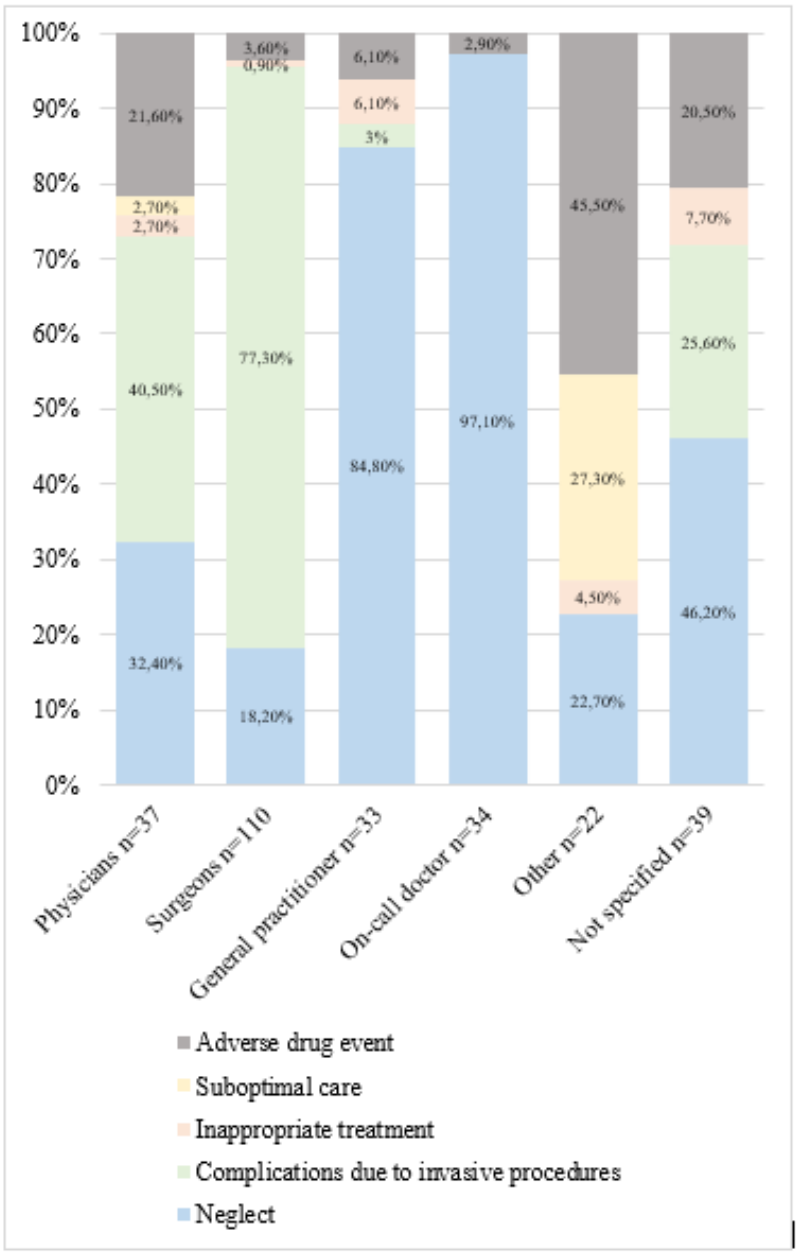

Figure 2. Type of iatrogenic event within each group of responsible medical profession. 
In only $22(8.0 \%)$ cases, other medical professionals were responsible such as nurses, radiographers and other care workers. Among these an adverse drug event occurred as the event in 10/22 (45.5\%) cases. Further investigation into these cases revealed that $6 / 10(60 \%)$ events were due to wrong dose or frequency.

\section{DISCUSSION}

Regarding death as a result of malpractice in the health care system, different terminology is used in the literature, and it proved to be a challenge finding the terminology which comprised the type of death of interest for this study. In this study, the terminology iatrogenic death was chosen as the best fit. latrogenic death was also used by Paula et al.10 Others have used unintended events 11 or adverse events 12 , medical errors 13 and medical malpractice9,14-16. When it comes to type of iatrogenic event, there is no standard classification, though the majority of studies $10,11,14$ used somewhat the same classification, and therefore this classification was applied in this study for the purpose of comparison. Our study found negligence and complication due to invasive procedures as the two most common iatrogenic events. Together they comprised $82.4 \%$ of all iatrogenic events. The same tendency was found in other studies.10,11,14 Also complications due to invasive procedures were the most frequent type of iatrogenic event among not only surgeons but also among the physicans. This calls for a discussion of whether this distribution is correct, disproportionate, or there is a selection in what type of event which leads to medicolegal autopsy. The disproportion could be caused by the circumstances that death following complications due to invasive procedures or negligence is immediately visible and therefore more likely to be reported to the police and undergo medicolegal autopsy. Adverse drug event, inappropriate treatment or suboptimal care are less evident for the parties involved in the process that leads to medico-legal autopsy and may therefore be underreported in our study. To support this point of view is the fact that physicians only account for $13.5 \%$ of the iatrogenic events, compared to the surgeons that account for $40 \%$.

An annual report published by The Danish Patient Safety Authority states that in 2018 there were 195,173 reported unintended events. Of these 96,996 reports $(49,70 \%)$ concerned medication including fluids.17 Furthermore there have been identified several incidents in Denmark where patients have received or potentially received the wrong medicine.18-20 Even though the vast majority of these patients survived, these circumstances indicate that adverse drug events are a problem and perhaps the rate of adverse drug events as the iatrogenic event leading to the death reported in this study (12\%) represents an underreporting. There are various explanations for this. One could be that the death is not unexpected because the patient is elderly and ill and thus there is nothing obvious that alerts the doctor of a mistake. Another explanation could be that is it difficult for the doctor examining the deceased to detect an adverse medical event during an external examination. Our data showed that when the iatrogenic event was adverse drug event the cause of death was not only poisoning (39.4\%) but also infection/inflammation (21.2\%) and cardiovascular diseases (18.2\%). All three causes of deaths are not necessarily evident during an external examination.
A study made by Bates et al.21 on adverse drug events found that adverse drug events occurred in $6.1 \%$ of admissions to the hospital, and that $1 \%$ of these were fatal. Furthermore, they found, that $42 \%$ of the life-threatening adverse drug events were preventable. This opportunity to take preventative initiatives emphasizes that it is extremely important to detect when an adverse drug event has occurred.

It could be argued that appointing one responsible person is unreasonable since doctors often work in teams and consult each other. However, appointing a responsible medical professional can reveal important information on a group level.9,11,14,15 Our study shows, that hospital doctors were involved in $53.5 \%$ of all cases, which is consistent with findings in other studies.9,11,14 This study found practitioners and doctors from the emergency service responsible for an equal amount of cases as Sørensen et al.11 at nearly the same frequency. Considering that Danish general practitioners deal with a large amount of patients, according to a report made by the Danish Ministry of Health only approximately $10.5 \%$ is referred to secondary care. 22 This is naturally a reflection of the fact, that general practitioners have a wide task assignment, and that patients treated at the hospital have more complicated and severe illnesses.22 General practitioners' records are not available for other doctors, and will therefore not be included in the evaluation regarding whether to contact the police or not. However, the general practitioners' journals are obtained in relation to the medicolegal autopsy, though this is rather late in the process of determining if a possibly iatrogenic event has occurred. Considering these aspects, it is difficult to determine whether the fact that general practitioners and doctors from the emergency service account for $24.4 \%$ of the iatrogenic deaths represent the frequency to be expected or is perhaps too low.

A limitation in this study may be the two different methods used to retrieve relevant cases. The frequency of iatrogenic deaths among the total number of medicolegal autopsies were higher in 2016 in which the cases were selected based on the autopsy introduction. This suggests that there could be relevant autopsy cases from 1992 to 2015 , that were not identified by only using the registration of 'iatrogenic death' in the 'RPA-sager' database. Sørensen et al.11 performed a one-year prospective study in 2009 comprising data from the Department of Forensic Medicine University of Copenhagen, and they found that in $13.6 \%$ of the autopsies performed the possible cause of death was unintended consequences of medical intervention. However, a study made by Madea et al.9 showed that the autopsy rates can vary markedly within regions and years. Madea et al. conducted a multicentre retrospective study in Germany over a 10-year period from 1990 to 2000. They found large differences in autopsy rates of malpractice cases varying from 1.9-20\% within regions. 14 Though it is possible that some cases of possible iatrogenic death were not identified, the results presented in this study are comparable with those of other studies. This could be an indication that the potential missing cases does not affect the results but rather the strength of the study.

Not all iatrogenic events lead to the death of the patient. The Harvard Medical Practice Study 12 found that adverse events occurred in $3.7 \%$ of hospitalisations, and $13.7 \%$ of these lead to the death. However, it can be discussed whether some deaths could have been prevented, had the adverse event not happened. Hayward and Hofer 13 finds that $6 \%$ of hospital deaths were probably or definitely preventable. Though, when 
they considered that the patient should have been expected to live 3 months or more outside the hospital had optimal treatment been given, only $0.5 \%$ of the deaths would have been preventable. This suggests that many of the patients exposed to medical errors are critically ill, and that preventing medical errors might not prevent the death of the patient.
Our study does not consider the severity of the patient's condition nor the expected prognosis had the iatrogenic event not occurred. The hope for this study is that the results could be useful in preventative initiatives, however they may only be relevant in preventing iatrogenic events and perhaps not in preventing death itself.

\section{REFERENCES}

[1] Pedersen FS. Antallet af rapporter om fejlbehandling sætter ny rekord: 19.03.2014, 2014.

[2] Langwadt L. Lægefejl koster 5000 liv om året. Ekstrabladet.dk: 11.04.2009, 2009.

[3] Schmidt AL. Hvert tredje minut bliver der begået fejl i det danske sundhedsvæsen. Politiken: 05.02.2014, 2014.

[4] Styrelsen for patientsikkerhed. Mission, vision og værdier. 2018, 23 July; https:// stps.dk/da/om-os/maal-og-opgaver/mission,-vision-og-vaerdier/.

[5] patientsikkerhed Sf. Udgivelser. 2018, 23 July; https://stps.dk/da/udgivelser/.

[6] Reinertsen JL. Let's talk about error. Bmj. 2000;320(7237):730.

[7] Den Store Danske G. 2018, 26 July; http://denstoredanske.dk/index. php?sideld=95790.

[8] Sundhedsloven. §179: Indberetning til politiet §180-181: Retslægeligt ligsyn §184185: Retslægelig obduktion. In: Ældreministerie S-o2018, November 2.

[9] Madea B, Preuss J. Medical malpractice as reflected by the forensic evaluation of 4450 autopsies. Forensic Sci Int. 2009;190(1-3):58-66.

[10] Paula P, Pottinger I, Kordina N, Schneider B, Risser DU. latrogenic death: A review of cases from 1990-2000 investigated at the Department of Forensic Medicine, Vienna. Wien Klin Wochenschr. 2011;123(17-18):526-530.

[11] Sørensen B, Lynnerup N. Fatal outcome after unintended events following medical intervention: a forensic pathological case survey. Research and Reports in Forensic Medical Science. 2014;4:11-17.

[12] Brennan TA, Leape LL, Laird NM, et al. Incidence of adverse events and negligence in hospitalized patients: results of the Harvard Medical Practice Study I. 1991. Qual Saf Health Care. 2004;13(2):145-151; discussion 151-142.
[13] Hayward RA, Hofer TP. Estimating hospital deaths due to medical errors: preventability is in the eye of the reviewer. Jama. 2001;286(4):415-420.

[14] Madea B. Medico-legal autopsies as a source of information to improve patient safety. Leg Med (Tokyo). 2009;11 Suppl 1:S76-79.

[15] Pakis I, Yayci N, Karapirli M, Gunce E, Polat O. Autopsy profiles of malpractice cases. J Forensic Leg Med. 2009;16(1):7-10.

[16] Casali MB, Mobilia F, Sordo SD, Blandino A, Genovese U. The medical malpractice in Milan-Italy. A retrospective survey on 14 years of judicial autopsies. Forensic Sci Int. 2014;242:38-43.

[17] Patientsikkerhed Sf. Dansk Patientsikkerhedsdatabase Aロrsberetning 2018. http:// stps.dk/da/udgivelser 2019.

[18] Pedersen FS. Fik for meget gigtmedicin: 12 patienter er døde efter fejlbehandling. Berlingske: 02.07.2019, 2019.

[19] Mirazei-Fard M, Baun LG. 46 fik forkert mængde blodtryksmedicin på grund af fejl i Sundhedsplatformen. Dr.dk: Danmarks Radio; 2019.

[20] Baun LG. Eksperter er bekymrede: It-problemer skaber tvivl om patienters medicinkort. Dr.dk2019.

[21] Bates DW, Cullen DJ, Laird N, et al. Incidence of adverse drug events and potential adverse drug events. Implications for prevention. ADE Prevention Study Group. Jama. 1995;274(1):29-34.

[22] Vedsted P, Olsen KR, Sørensen TH, Bech M, Gyrd-Hansen D. Henvisningsmønstret i almen praksis. En litteraturgennemgang: Ministeriet for Sundhed og Forebyggelse; 2008. 